術前化学療法により切除しえた肺動脈浸潤肺癌の 1 例

広島大学原爆放射能医学研究所腫汮外科

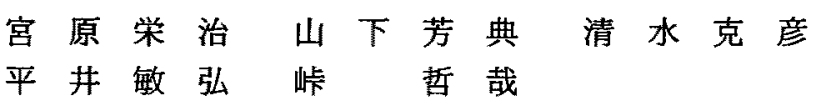

症例は70歳，男性。咳濑を主訴に受診し，精査にて左上葉原発の扁平上皮癌と診断さ れた。術前精查にて左主肺動脈根部に浸潤を認めたため治癒切除は困難と半断し，シス プラチン, ビンデシンによる術前化学療法を 2 コース施行した. 左肺動脈根部への浸潤 が消失し同部での切離が可能となったため左肺摘除術により完全切除となった，摘出標 本の組織学的検索では， $\mathrm{B}^{1+2}$ 区域気管支周囲リンパ節に低分化型扁平上皮癌の転移が認 められ一部は肺動脈外膜に浸潤していたが，腫激中心部原発巣には腫湟細胞は認められ なかった. 術前化学療法の組織学的効果は Ef. 2 であった。術後 3 年が経過した現在, 再 発を認めていない. 術前化学療法が局所制御に有効であり、微小転移巣の制御に有効で あったと推察される.

索引用語：非小細胞肺癌, 術前補助療法

\section{はじめに}

術前補助療法（induction therapy）は，不完全切除 となる症例に対し局所をコントロールし down stage することにより治癒切除を可能とし，手術成續の向上 を計るために予後不良の川期肺癌に対して用いられて きだ2).また,動脈系に浸閏した T4 症例は予後不良と 報告されている3).今回, 肺動脈浸潤のため治癒切除は 困難と判断したが, 術前化学療法後により治瘉切除可 能となった症例を経験し，良好な結果を得たので報告 する.

\section{症例}

症例：70歳, 男性,

主訴：咳濑。

既往歴：66歳時, 胃癌にて幽門側胃切除 (T1N0M0, Stage I A).

家族歴：特記すべことなし。

整煙歴：25 45歳, 45本/day, $B I=900$.

現病歴: 平成 9 年 5 月中旬, 咳嗽直覚し近医 A 医 院を受診し, 胸部 $\mathrm{X}$ 線にて肺炎と猃断され内服薬を処 方された．その後血痰も自覚するようになったため，

2000 年 8 月30日受付 2000 年10月19日採用 〈所属施設住所〉

于734-8553 㳂島市南区霞 $1-2-3$
6 月 3 日, 近医 B 病院を紹介受診した。胸部 CT にて 左肺門に径 $3 \mathrm{~cm}$ の腫溜影打よび左上葉の肺炎が認め られた。

6月13日，精查加療を目的に当科に紹介入院した。

入院時現症：身長 $159 \mathrm{~cm}$, 体重 $48 \mathrm{~kg}, 1$ 力月で $2 \mathrm{~kg}$

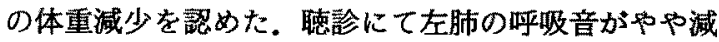
弱していたが，ラ音は鳃取されなかった。眼瞼・眼球 結膜に貧血・黄疸は認めなかった。

入院時血液所見: 白血球数 $5,800, \mathrm{CRP} 0.3$ と正常範 囲内であり，その他の血液一般ならびに血清生化学検

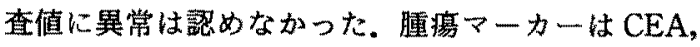
SCC, NSE, SLX とも正常範囲内であった。

胸部レントゲン：正面像において左肺門に $4 \mathrm{~cm}$ 大 の㯵瘤陰影を認め, 左上肺野には透過性の低下が認め られた。また，側面像においても大動脈弓直下ょり肺 尖部に向かい透過性の低下が認められた（Fig.1).

胸部 CT: 左上葉に $4 \times 3 \mathrm{~cm}$ の充実性腫瘍影を翗 め，末梢には閉塞性肺炎を合併していた．肺門では腫 㰾影は左主肺動脈根部に接し浸潤が疑われた．気管前 および大動脈弓傍りンパ節の腫脹を認め N2 と㟝断し た (Fig. 2).

気管支鏡：左上葉支口は腫湟で閉塞して打り，下幹 も正排され狭窄していた，気管支鏡下生検で低分化型 扁平上皮癌（Group V) と診断した。 
肺動脈造影：CTにて左肺動脈への浸潤が疑われた ため肺動脈造影を施行した，肺動脈幹から $1.5 \mathrm{~cm}$ の左 主肺動脈に壁の不整が認められ腫瘍浸潤と診断した

(Fig. 3). 同部は左右肺動脈分岐後であるが心膜内部 と考え $\mathrm{T} 4$ とした。

以上より，左上葉扁平上皮癌， T4N2M0 cStage III $\mathrm{B}$ と診断した。左主肺動脈根部への浸潤を疑い左肺摘 除術にても肺動脈切離断端に癌が遺残する可能性があ ると判断し，シスプラチン，ビンデシンによる化学療 法（VP 療法）を施行した。

術前化学療法：VP療法を 2 コース施行した。すな わち, Day 1 にシスプラチン $80 \mathrm{mg} / \mathrm{m}^{2}$, ピンデシン 3

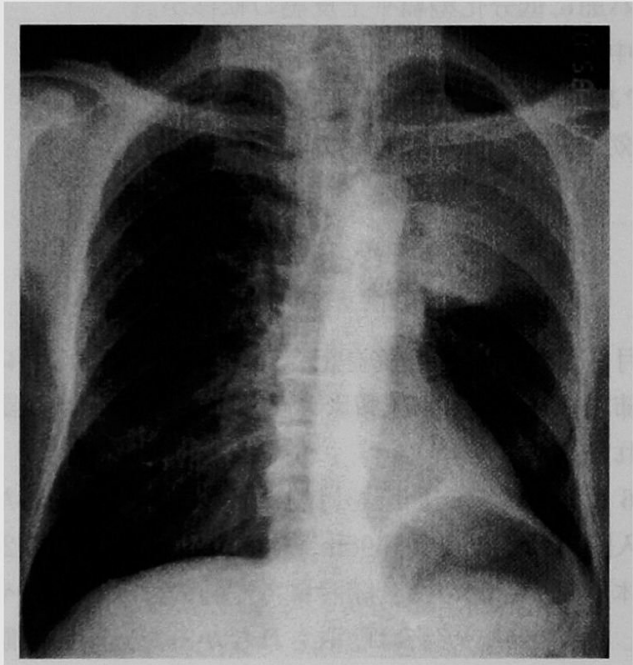

Fig. 1 : Chest $\mathrm{X}$-ray shows a $40 \times 40 \mathrm{~mm}$ mass shadow in the left hilar lung field with a volume loss of the left upper lung field. $\mathrm{mg} / \mathrm{m}^{2}$, Day 8 にピンデシン $3 \mathrm{mg} / \mathrm{m}^{2}$ を点滴静注し た. 7 月 4 日，1コース目を開始. Grade 2 の白血球 滅少を認めた。 8 月 6 日，2 コース目を開始. 2コー ス目は Grade 3 の白血球減少を認めたため G-CSFを 投与した。

化学療法開始後66日目の CT では，腫瘍は瘃痕化し 85\%の縮小を認めた。また大動脈弓傍リンパ節の腫脹 は消失し，気管前リンパ節の腫脹は縮小した(Fig.4). 化学療法施行後の肺動脈造影では, 左主肺動脈根部の 壁の不整は消失した (Fig.5). cStage は T4N2M0 II B から T1N1M0 II A と down Stage され, 治癒切除 可能と判断し, induction therapy 施行後 100 日目の 10 月 9 日に左肺摘除術を施行した。

手術所見：10月 9 日，左後側方切開，第 5 助間にて 開胸した。癒着は認められず，胸水，胸膜播種も認め

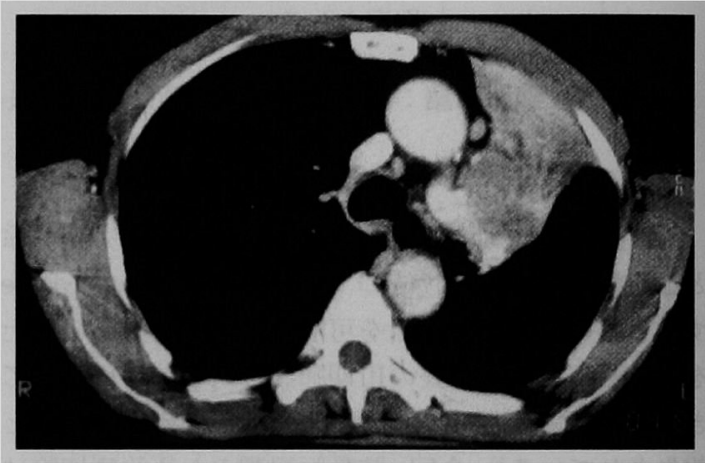

Fig. 2 : Chest CT shows a $40 \times 30 \mathrm{~mm}$ heterogeneous mass with an peripheral atelectasis, an invasion to left pulmonary artery close to pulmonary trunk and pretracheal lymphnode swelling.

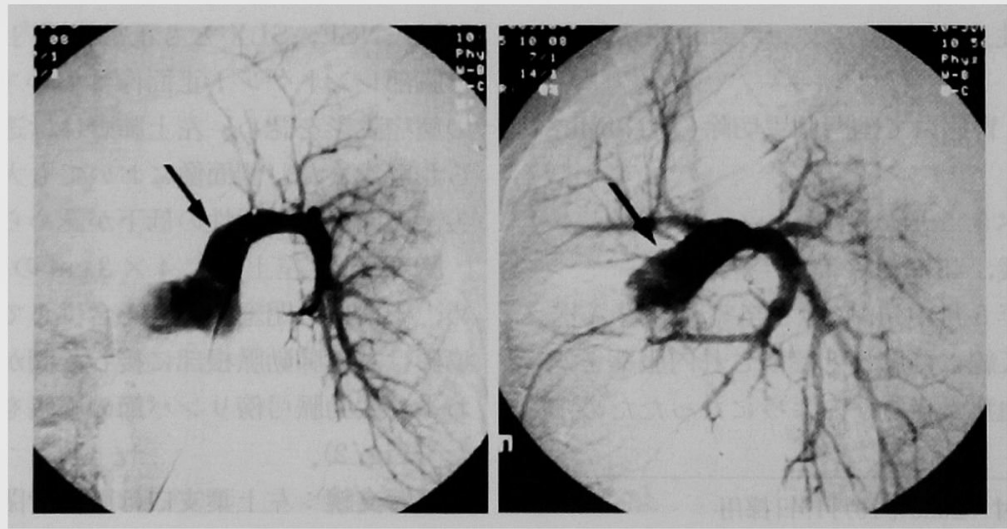

Fig. 3 : Left pulmonary arteriogram reveals tumor invasion to left pulmonary artery $1.5 \mathrm{~cm}$ from pulmonary trunk (arrow). 
られなかった，肺に腫瘤は触知しなかった。心嘦を切 開し，左主肺動脈根部およびその末梢肺動脈への剝離 を試みたが，同部は䄉維化により高度を増していたが 明らかな腫湯浸潤は認められず剥離可能であった。術 前画像診断にて浸潤の疑われていた部位は切除すべく 左主肺動脈を根部にて結絷切離した．迅速病理検査に て肺動脈断端に腫瘍細胞は認められなかった(PA-). 左主気管支周囲にも腫瘍漫潤は認められず十分剝離し た後自動吻合器にて切離し左肺摘除術を施行した．ま た,ND2a のリンパ節郭清を施行したが, 化学療法施行 前にCT で認められたNo.3, 6 のリンパ節に肉眼的に 転移は諗められなかった，手術所見としては， PODOE0PMON0であった.

摘出標本および病理組織所見：摘出標本では, 胸膜 面，縦隔面，また割面においても明らかな腫瘍は認め られなかった．組織学的には，腫瘍中心部には泡洙化

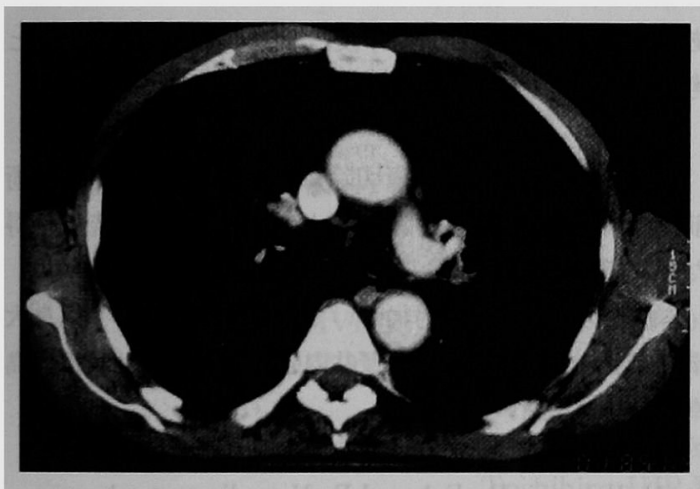

Fig. 4 : Induction chemotherapy resulted in extreme reduction in size and lymphnode on chest CT.
したマクロファージを認めるものの腫場細胞は認めら れず,また気管支上皮も再生上皮に置き変わっていた. しかし， $B^{1+2}$ 区域気管支周囲リンパ節（\#13）には viable な腫煌細胞を認め(Fig. 6 a), 同部のリンパ節 の一部は肺動脈外膜に浸潤していた(Fig. 6 b)。郭清 された47個のリンパ節のうち \#13の 2 個のみに低分化 型扁平上皮癌の組織学的な転移を認めた. 組織学的効 果は Ef. 2 であった。組織学的病期分類は pT0N1M0 pStage IIA であった.

術後経過：術後循環動態が不安定であったため ICU にて管理したがその後順調に回復し，第29病日に 退院した. 現在術後 3 年を経過したが再発を認めてい ない.

\section{考 察}

術前補助療法（induction therapy）は手術成績の向 上を計るために予後不良のIII期肺癌に対して用いられ てきた。 そして, 治瘑切除率の向上, 遠隔転移再発の 抑制を認めた術前補助療法の報告は增えている ${ }^{122)}$. 主 に縦隔リンパ節陽性症例に対し無作為比較試験により induction therapy の有用性に関する報告がみられ, 生

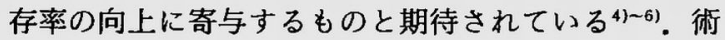
前化学療法の 2 大目的は，1) 微小転移巣の制御，2） down stage を図り治癒切除率を向上させ可能ならば 切除範囲の縮小を図ることである7．動脈系に浸潤し た T4 症例は予後不良と報告されており ${ }^{3)}$, 術前化学療 法を施行することが, こうした症例の予後を向上させ る可能性がある。

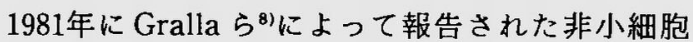
肺癌の進行症例に対するシスプラチン, ビンデシン併

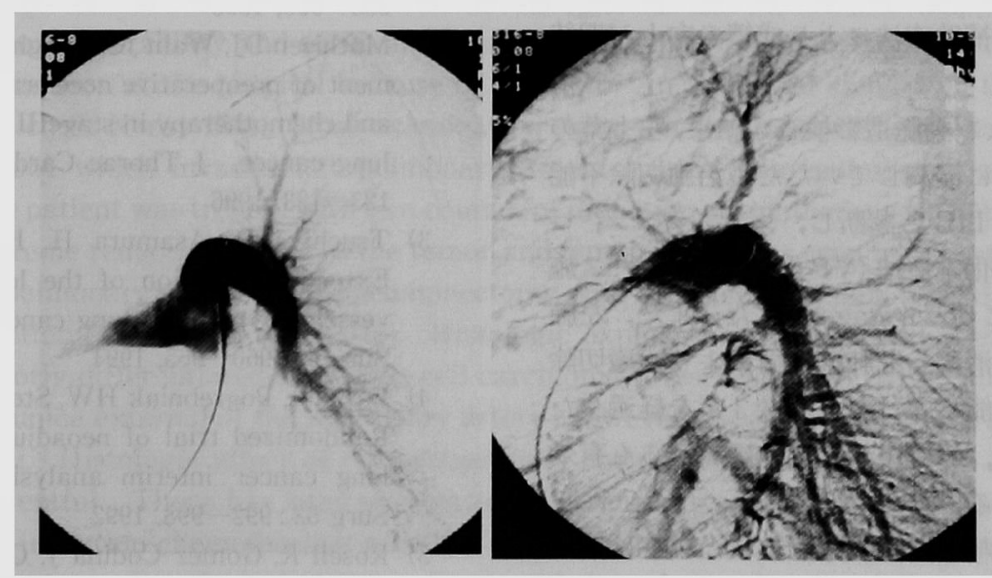

Fig. 5 : The findings of invasion to the left pulmonary artery completely disappeared on pulmonary arteriogram after induction chemotherapy. 

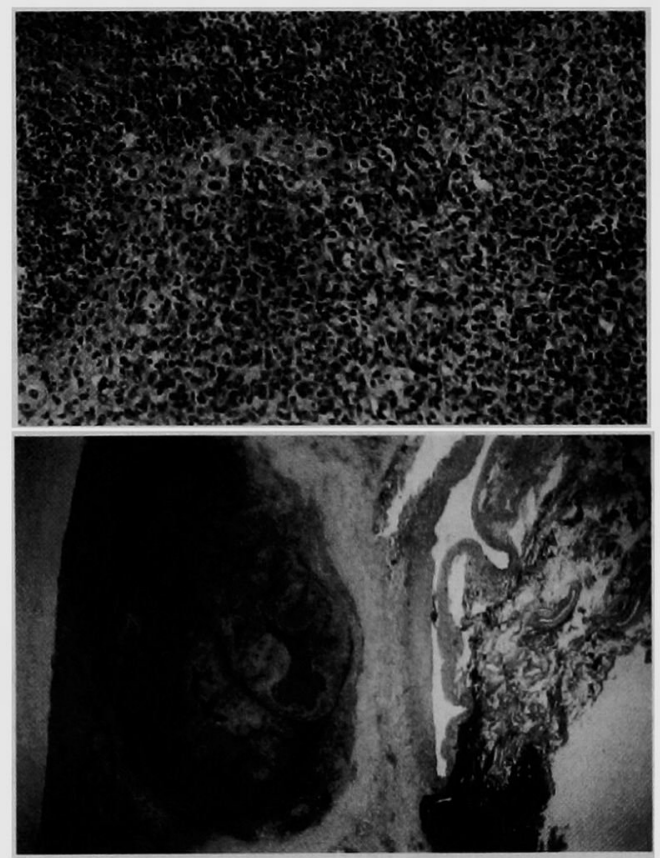

Fig. 6: Histological section of peri-bronchial lymphnode around $\mathrm{B} 1+2$ reveals a metastasis of poorly differentiated squamous cell carcinoma $(\mathrm{HE} \times 100)$ and slight invasion on the adventitia of left pulmonary artery.

$\frac{\mathrm{a}}{\mathrm{b}}$

用療法 (VP 療法) は多くの研究者によって追試され 30〜 40\%の高い奏功率が報告されている ${ }^{910)}$. VP 療法 は, 進行非小細胞癌に対する標準的な化学療法の 1 つ であり, 日本においても汎用されている7゙.また, 近年, ナベルビン, タキソールを用いた優秀な化学療法の報

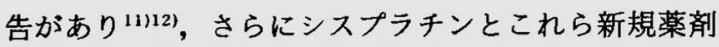
との併用による術前補助療法により成績の向上が期待 される。

自験例は, CT および動脈造影検查の結果, 左上葉の 腫瘍が左肺動脈根部に浸潤していたため治癋切除不能 と判断した. cStage IIIB と診断し, シスプラチン, ビ ンデシンによる術前化学療法 (VP 療法) を 2 コース施 行後, cStage II A に down stage しえた。また，左肺 動脈根部への浸潤が消失し左肺摘除術により治痣切除 を施行することが可能になった。術後 3 年を経過した 現在, 再発を認めず, 転移巣の制御の観点からも有効 であったと考えられる。

術前化学療法の投与期間, 投与回数については, 2 コースと 3 コースの奏効率には差はなく 3 コースでは 術後合併症の頻度が高くまた化学療法終了から手術ま
での期間延長が羿められたことから 2 コースが適して いるとの報告もある ${ }^{13)}$ 。また 2 コース終了時画像診断 にて左肺動脈根部への浸潤が消失し治癒切除術が可能 と判断したため，2コース終了後に左肺摘除術を施行 した.

術前放射線療法の有効性については，化学療法と放 射線療法の併用による高い奏功率が報告され(4), 今後, 術前補助療法にも奇与すると思われる。しかし，一方 では,放射線併用により合併症が高率に認められ ${ }^{15)}$, た，放射線化学療法後の手術関連死は $23 \%$ あったと の報告もあり ${ }^{16)}$, 術前放射線治療の併用に関しては今 後, 検討を要する課題であろう。

組織学的検索では，原発部位には癌細胞は確認でき なかったがリンパ節にごく僅かの癌細胞の遗残を認め た. 術前化学療法が奏効した完全切除例の 5 生率は34 \%との報告もあるが1), 組織学的治療効果が Ef. 2 や 1 の治療成績は, 術前化学療法非施行例と同様に不良て あるとの報告もあり ${ }^{17)}$, 今後, 厳重な follow が必要と 考えられる。

\section{結 語}

肺動脈浸潤のため治癒切除は困難と判断したが, 術 前化学療法後に治㾑切除可能となり，良好な結果を得 たので報告した.

本症例の病理学的検討について御教示いただいた広島大 学医学部第 2 病理学教室教授井内康輝先生, 同助教授武島 幸男先生に深謝いたします。

\section{文献}

1) Bonomi $P$, Faber LP : Neoadjuvant chemoradiation therapy in non-small lung cancer, the Ruch University experience. Lung Cancer 9 : 383-390, 1993

2) Mathisen DJ, Wain JC, Wright C, et al : Assessment of preoperative accelerated radiotherapy and chemotherapy in stageIIIA (N2) non-small lung cancer. J Thorac Cardiovasc Surg 111: 123-133, 1996

3) Tsuchiya $R$, Asamura $H$, Kondo $H$, et al: Extended resection of the left atrium, great vessels, or both for lung cancer. Ann Thorac Surg 57 : 960-965, 1994

4) Pass HI, Pogrebniak HW, Steinberg SM, et al : Randomized trial of neoadjuvant therapy for lung cancer: interim analysis. Ann Thorac Surg $53: 992-998,1992$

5) Rosell R, Gomez-Codina J, Camps C, et al : A randomized trial comparing preoperative chemotherapy with surgery with surgery alone 
in patients with non-small-cell lung cancer. $N$ Engl J Med 330: 153-158, 1994

6) Roth JA, Fossella F, Komaki $R$, et al : A randomized trial comparing perioperative chemotherapy plus surgery with surgery alone in resectable stage IIIA non-small-cell lung cancer. J Natl Cancer Inst 86:673-680, 1994

7) 根来俊一：進行非小細胞肺澢の治療. 癌と化療 $25: 1671-1679,1998$

8) Gralla RJ, Casper ES, Kersen DP, et al : Cisplatin and Vindesine combination chemotherapy for advanced carcinoma of the lung: A randomized trial investigating two dosage schedules. Ann Intern Med 85:414-420, 1981

9) Sugarbaker DJ, Herndon J, Kohman LJ, et al : Results of cancer and leukemia group B protocol 8935. A multiinstitutional phase II trimodality trial for Stage IIIA (N2) non-small -cell lung cancer. Cancer and Leukemia Group B Thoracic Surgery Group. J Thorc Cardiovasc Surg 109:473-485, 1995

10) Wada $H$, Hitomi $S$, Teramatsu $T$ : Adjuvant chemotherapy after complete resection in nonsmall-cell lung cancer. West Japan Study Group for Lung Cancer Surgery. J Clin Oncol $14: 1048-1054,1996$
11) Depierre A, Lemarie E, Dabouis $G$, et al: A phase II study of navelbine (vinorelbine) in the treatment of non-small-cell lung cancer. Am J Clin Oncol $14: 115-119,1991$

12) Fossella FU, Lee JS, Shin DM, et al : Phase II trials of docetaxel for advanced or metastatic platinum refractory non-small cell lung cancer. J Clin Oncol 13:645-651, 1995

13）吉村雅裕, 呯田紀明, 室谷陽裕他：韭小緗胞肺㮩 に对する術前補助療法の意義一病理学的 N2 確諗 症例の检討一，日呼外会誌 $10: 754-759,1996$

14) Byhardt RW: The evolution of Radiation Therapy Oncology Group (RTOG) protocols for nonsmall cell lung cancer. Int J Radiat Oncol Biol Phys 32:1513-1525, 1995

15) Macchiarini $P$, Chapelier AR, Monnet I, et al : Extended operations after induction therapy for stage III b (T4) non-small lung cancer. Ann Thorac Surg 57:966-973, 1994

16) Foller WC, Langer CJ, Curran Jr WJ, et al : Postoperative complications after combined neoadjuvant treatment of lung cancer. Ann Thorac Surg 55:986-989, 1993

17) Martini N, Flehirger BJ : The role of surgery in N2 lung Cancer. Surg Clin North Am 67 : $1037-1049,1987$

\title{
A CASE OF CURATIVE RESECTION FOR NON-SMALL CELL LUNG CANCER WITH INVASION TO THE PROXIMAL PULMONARY ARTERY AFTER INDUCTION THERAPY
}

\author{
Eiji MIYAHARA, Yoshinori YAMASHITA, Katsuhiko SHIMIZU, \\ Toshihiro HIRAI and Tetsuya TOGE
}

Department of Surgical Oncology, Research Institute for Radiation Biology and Medicine, Hiroshima University

Background : Several recent clinical studies have suggested that induction therapy can improve the histologically poor resectability and survival of patients with lung cancer in stage IIIA and IIIB. A 70year-old man was seen at the hospital because of a cough. An abnormal shadow in the left hilus was pointed out on a chest $\mathrm{X}$-ray film. Close examination showed a squamous cell carcinoma originated in the left upper lobe which invaded left pulmonary artery $1.5 \mathrm{~cm}$ from pulmonary trunk (cT4N2M0, cStageIIIb). The patient was treated with two courses of induction chemotherapy (CDDP $80 \mathrm{mg} / \mathrm{m}^{2}+\mathrm{VDS}$ $3.5 \mathrm{mg} / \mathrm{m}^{2}$ ). Extreme reduction in size of the tumor and lymph nodse was seen with disappearance of the invasion to left pulmonary artery. Left pneumonectomy with mediastinal lymph node dissection resulted in curative resection (pTON1M0, pStagella). Histologic exploration of the resected material disclosed metastasis of poorly differentiated squamous cell carcinoma to peribronchial lymph nodes and a partial involvement of tunica external of the pulmonary artery ; however, there were no tumor cells in the center of the tumor foci. Histologic effect of the preoperative chemotherapy was rated Ef. 2. Postoperative course was uneventful. There has been no sign of recurrence as of 3 years after the operation. It is thought that the induction chemotherapy greatly contributes to local control of the primary foci as well as control of minute metastatic foci in the patients with far advanced non-small cell lung cancer. 